\title{
Dynamics Development of Hizbut Tahrir Indonesia (HTI) and Indonesia's Economic Reality
}

\author{
Mohamad Zaim \\ Interdisciplinary of Islamic Studies, Islamic State University of Sunan Kalijaga
}

\begin{abstract}
In the last of 2017, government has banned Hizbut Tahrir Indonesia (HTI) because it has claimed a contradiction with the ideology of Pancasila. HTI is a political party that has Islamic ideology and aims to establish based on Khilafiah Islamiyah. It is in order to disengage the people from colonialism and capitalism. However, khilafiah did not show the good effect practically. Moreover, it cannot create social justice. The future practiced of khilafah islamiyah system in Indonesia might cause blood battle of sovereign as in Khalifah Umar era. The conflict of sovereign battle took a part in Islamic development. The different social status is the one factor. This also becomes a problem for the Indonesian government that they should offer a solution for the sake of Indonesian foundation to make the equitable and prosperous society.
\end{abstract}

DOI: $10.7176 / J P C R / 41-03$

\section{Introduction}

Towards the end of the year 2017, public had been surprised by the statement from the Government which banned Hizbut Tahrir Indonesia (HTI). The Government state that the HTI organization is forbidden in Indonesia. Statement of dissolution of the HTI as an illegal organization, it is read by Wiranto as Menkopolhukam (the Coordinating Minister of politics, law, and security).

There are three reasons presented by the Government relating to the dissolution of the HTI. First, as a legal mass organization, HTI does not implement the positive role for taking part in the development process in order to achieve national goals. Second, HTI strongly indicated doing activities that contrary to the purposes, and principles, and the characteristic based on Pancasila and the 1945 Constitution of Indonesia which written in constitution No. 17 Year 2013 about mass organization. Third, the activities of HTI have led to the collision in the community that could threaten the safety and order of society, as well as jeopardizing the integrity of NKRI (Erdianto, 2017).

After HTI is expressed as an illegal mass organization, the government issues a Government Regulation in Lieu of Law number (Perppu) 2 Year 2017 which is Perppu number 17 Year 2013 on mass organization. Through Government Regulation in Lieu of Law of mass organization can be a Foundation for strengthening the Government prohibits mass organizations which are opposed to the Pancasila, one of them is HTI. Post issuance of these Регрри of mass organization, HTI and several parties filed a protest. Even the HTI does a lawsuit to the Constitutional Court (MK) over Pегрри Mass Organizations which is issued by the Government. In this review, not analyze the issue of the Mass Organization Perppu. However, this review will probe the dynamic development of the HTI up to illegal organizations which is considered by the Government.

Presence of Hizbut Tahrir in Indonesia as an Islamic organization, it is not born out from empty space. There is a dynamic in space historical relationship that cause the presence and existence of HTI. As the extra parliamentary Islamic movement which declared as illegal organizations, of course many factors that lead to that case. Before researcher analyze any further about the dissolution of the HTI, it is better the researcher explains the history of existence Hizbut Tahrir in Indonesia as well as the dynamics of its development. Then the analysis of the reality of the dissolution of the HTI by Governments is a part which is inseparable. Through this kind of reading can make us clearer to respond on that issue.

\section{Look at History: The Birth Roots of the Hizbut Tahrir}

Post World War II and the establishment of the United Nations as an international organization, which has objective to prevent international conflict and occupation of countries in the world. However, there is a contradiction between the das sein and das sollen, in fact that the occupation of the others country still occurs. One of them is in the Middle East. Capitalism is a doctrine which aims for capital accumulation, this can be done through the practices of colonialism-imperialism, for example the occupation that occur in the Middle East countries.

Occupation conducted by Western Nations over the countries in the Middle East region resulted in the suffering of the people, because of the absence of Justice and welfare. Even, social inequality increases rapidly, where the ruling class cum entrepreneur is getting richer, while the poor citizenry are going poorer and suffer more. This encourages An-Nabhani Taqiyuddin founded the political party which aims at freeing the people from the handling of colonialism-capitalism. Hizbut Tahrir is a political party which has an Islamic ideology which aims to uphold the Caliphate Islamiyah. Taqiyuddin An-Nabhani is a man from the Palestina, which 
establish an Islamic-based political party. Departing from reality in Jordan, the Palestinian, Arab or other Middle Eastern countries, pushing An-Nabhani Taqiyuddin founded Hizbut Tahrir as the party for the liberation of the Muslims in the year 1953 in Al Quds, Jordan (Samarah, 1999). The purpose of the establishment of Hizbut Tahrir as an instrument to free the people from the shackles of colonialism-capitalism and even rise up khilfah Islamiyah led by a Caliph.

Hizbut Tahrir intends to resurrect the Muslims from a very severe downturn, freeing the people from the ideas, the system of legislation, and the law of kufur, as well as freeing them from handling dominance and influence of kafir country. Hizbut Tahrir intends to also rebuild the Caliphate Islamiyah on the world, so the law that lowered the Almighty God can be put in place again. Leaders are appointed and oath by the Muslims to be heard and adhered in order to run a Government based on Islamic law and carry treatise Islam all over the world with the Da'wah and jihad (https://kumparan.com/salmah-muslimah/sejarah-hizbut-tahrir-di-indonesia, 2017).

\section{Birth Roots Hizbut Tahrir in Indonesia and Its Development}

After he founded Hizbut Tahrir, Hizbut Tahrir is experiencing development and spreading to parts of the world, one of them in Indonesia. Chusna (2014), the influx of Hizbut Tahrir in Indonesia cannot be separated from the role of a citizen of Australia, namely Abdurrahman al-Baghdadi. With the help of K.H. Abdullah (founder of pesantren Al - Ghazali, Bogor), have encouraged him to stay in Indonesia to do Da'wah in order to introduce the ideas of Hizbut Tahrir in boarding school and campuses (Chusna, 2014). The influx of Hizbut Tahrir in Indonesia country is at 1982-1983. Infiltration of Hizbut Tahrir ideas is made by klaindesten with the Mission of establishes a Khilafah Islamiyah, so Islamic law contained in the Qur'an must be applied in a sich (Taufiq Adnan Amal et al, 2004). The new order's repressive political system of Hizbut Tahrir cause Hizbut Tahrir does not appear on the surface or to be open, so that movement that carried out underground. Infiltration and ideological indoctrination slowly and continuously is the ways that is done by HTI to influence Muslims. Especially for those who have understanding of religion is still shallow. This case causes the emergence of Hizbut Tahrir in the Era of the new order in quantity is not significant enough.

In the first 10 years, the numbers of cadres of Hizbut Tahrir in Indonesia are 17 people. However, the movement carried out underground, but by the time the intensity and the commitment to recruit and to cadre a successful member. During the next 10 years, the effect of duplication the development of cadres of Hizbut Tahrir is simply growing exponentially throughout Indonesia (Victoria, 2013). Then in the middle of the third 10 years, $D a$ 'wah undertaken by Hizbut Tahrir distributed in 33 provinces with more than 300 counties and cities in Indonesia. In 1990, the $D a$ 'wah that is undertaken by Hizbut Tahrir carried out in two stages (Ali, 2017). First, the $D a$ 'wah is undertaken by door to door to the homes of citizens. Second, Da'wah is undertaken to mosques, offices, factories, and house.

Though done in klandestein, the two phase of da'wah was done until the collapse of the power of the new orde. The second stage of the strategy is the effect on the improvement of cadres as well as Hizbut Tahrir believer significantly. The increase in quantity the number of Hizbut Tahrir cadres spread across Indonesia exponentially of militancy and commitment the cadres themselves. About this case will be reviewed in a separate review in the section of Da'wah methods and cadre recruitment conducted by Hizbut Tahrir. However, the movement carried out underground, but it does not resist the Hizbut Tahrir cadres to expand their wings. In addition, this chapter aims to develop organizations are also part of the struggle of establishing the Islamic jurisprudence. The peak of underground movements carried out by Hizbut Tahrir political climate at the time of the new orde reached the point after the culmination. The political configuration of the new orde to Reformation is a fresh breeze for Hizbut Tahrir to declare himself openly.

Although Hizbut Tahrir rejects democratic system, however this organization uses the instruments of democracy to spread their wings. Reform that is characterized by the liberalization of politics is momentum for any individual or group that during the new orde run in underground is now blatantly shows its existence. Because of political liberalization, as the spirit of reform has been to guarantee every citizen opinion, assembly, and association. As mushroom in rainy season, there are various social-political organization is born, either the extreme ideology left or right, well that is fundamentalist, radical, Orthodox as well as moderate opportunist has grown and developed. One of them namely, Hizbut Tahrir (HTI) has leveraged the democratization in Indonesia to reveal the existence of itself. This can be seen from a political movement undertaken by HTI when reform openly, publicly.

When Indonesia entered the reform era, it is a wide open for momentum Hizbut Tahrir to legalize his movement. Hizbut Tahrir does great blow in 2002 with successfully deploying an international Khilafah Islamiyah Conference in Senayan, Jakarta, not less than 5000 people attended the event. The success continued with the activities of action against United States assault demo against Afghanistan. Hizbut Tahrir movement increasingly to the forefront when it managed to roll out a long march that followed 12,000 cadres and sympathizers of the MPR Annual Session, in 2002, demanded the implementation of Islamic jurisprudence. Then, on 29 February 2004, Hizbut Tahrir back stage a long march from the monument to the Hotel Indonesia 
Roundabout by involving 20,000 members with Sharia enforcement agenda and the Caliphate (Chusna, 2014).

Hizbut Tahrir has been utilizing the momentum to declare itself as a political organization openly. This means that the klandestein ways or underground movements have been abandoned. This can be seen in the activity of Hizb ut-Tahrir in the socio-political life in Indonesia. Although it has declared itself as a political organization, but not evolution as a political party, so that it can be referred to as extra parliamentary organization. However, in the future is very possible to become a political party to seize power when it already had a strong mass base. This causes as social and political organization, not just base it on sheer religious morality. Motion made by HTI is not just to Da'wah about the teachings of Islam. Nevertheless, through the Dawah movement aims to uphold the ideals of the founding khilfah islamiyah. Therefore, it is very possible when it has a mass base which evolve into a political party. The goal is of course to seize political power. Through political power, then the ideals of Sharia enforcement can be applied.

Although declaring himself a political organization, but HTI is listed as a political organization in 2006 (decision letter the Direktorat Jenderal Kesatuan Bangsa dan Politik Kementerian Dalam Negeri Nomor 44/D.III.2/VI/2006). While the organization incorporated is declared as the legal organization in 2014 (The decision letter of the Minister of law and human rights number AHU-00282.60.10.2014 about the status of a legal entity HTI). After HTI legalize as organization with legal entity, HTI doing political movement freely. This can be seen in 2007, HTI has presented the Conference the Caliphate Islamiyah in Gelora Bung Karno Stadium. Around 80 thousand participants attended the event. The Organization of this Conference to commemorate the event of the collapse of the Caliphate Ustmani Turkey dropped by Kemal Pasha, led to the collapse of the dynasty Islamiyah (Novel, 2007). The themes raised in the Conference of "the Empire's Time leading the world", and then the rule of the Caliphate islamiyah is very important. HTI state that caliphate idea is the antithesis of the colonial system, as was the case in Islamic countries that were colonized by the West, even this also happens in Indonesia which was still colonized. Therefore, the idea of a Caliphate with implementing Sharia in kaffah is the solution over the problem.

Beside the case above, there are still many political movements performed by HTI, however will not be reviewed in their entirety in this article. It is just that by the mid of the year 2017 HTI state to establish the khilfah Islamiyah immediate. On April 23, 2017, HTI return the International activities of the Caliphate forum will hold a Hall Sudirman, South Jakarta (Hindarto, 2017). Even a cry or a discourse to hold forum Caliphate also appeared in various areas in Indonesia, one of them in Yogyakarta and East Java. The existence of the Caliphate discourse forum activities encourage the police issued a disclaimer of the activities held by the HTI. This is due to the police that the event that would interfere with the safety and order of society Jakarta. Moreover, the conditions of Jakarta which hit by religious issues dragged the Governor of DKI Jakarta over religious sacrilege case. Increasingly rampant appeal organization of the Empire forum encourages the authorities disperse at once banned the activities of the Organization of the HTI.

Although HTI has disbanded and declared as illegal organizations, but that we should be aware of regarding the conviction of HTI Caliphate to establish the Khilafah Islamiyah as top solutions to problems that occur in the world and Indonesia. Then, the strategy pattern of the movement to recruit the cadre makes HTI as a large organization. It also has to be parsed on the logic of the Government upon the dissolution of the HTI as well as how the Government anticipates that movement that could lead to the disintegration of the nation. Before the breakdown of confidence over the establishment of Caliphate Even HTI Islamiyah as solutions to the national problems, in advance will be reviewed on fundamental issues faced by Indonesia. Departing from the problem is that customize the initial presence of ihkwal HTI with his idea about establishment of Islamic jurisprudence as a solution over the issue. On the description of this time will be focused on Indonesia's economic reality with the social inequality and sharp enough as things relating to that customize the HTI is calling for Islamic jurisprudence as a solution for the realization of Justice and social welfare.

\section{The Dynamics of the Development and Strategy of Da'wah HTI}

As has been described in the early sections relating to the development of the HTI, which at the beginning of the new orde, there are only a dozen cadres, however, when the era of the Reformation there were tens of thousands the number of cadres that are scattered throughout the province in Indonesia. Of course this correlate with the Da'wah strategies which undertaken by HTI itself. Two factors led to the great and became the HTI openly spread for khilfah islamiyah (BPH UMY, 2012). First, the internal factors, confidence, and trust for any cadres' khilfah system will reestablish by HTI islamiyah. This is due to the strength of the ideology building embedded in each cadre HTI, so that they are without a doubt the deploying of International Conference the Caliphate Islamiyah and demanded the Government to implement Sharia. A mature ideology of any cadres HTI is certainly correlate to the system of cadre is done. Cadre recruitment strategies undertaken by HTI there are four stages, namely:

1. construction and cadre (Tastqif stage)

2. interaction with people (stage Tafa'ul ma'a al-ummah) 
3. power interpretation (Istilam al-hukmi)

4. halaqah-halaqah that discuss about the application of Islamic Sharia and the application of the system of Khilafah Islamiyah (Sodhiq, 2016).

Da'wah movement carried out by Hizbut Tahrir is slow in the beginning. To make it mature, a halaqah takes many years. This is due to the book for coaching that must be studied quite a lot. Moreover, the methods of book explanation were originally written in Arabic. It has to be read in each paragraph, then explained the content and understanding by the teacher of halaqah, so it is not possible in short time (Victoria, 2013). However, this way has made cadre HTI matured in ideology. The maturity of this ideology will relate to commitment and consistency of the cadres in his fight.

The pattern of cadre who carried out an intensive course in addition to the dialogue that was conducted also indoctrination, slowly infiltrating, systematically and structured are the mature cadre recruitment strategy. Through this has strengthened its cadres to reject the form of any ideology other than Islam. Islam is the only ideology that not only saves humankind in the hereafter, but also in the world. It also departs from the few studies done by cadres against Hizbut Tahrir ideology of socialism or communism and liberalism-capitalism. Both the ideological spectrum, for Hizbut Tahrir is considered fail in realizing social justice for the people. This is confirmed by the existence of inequality of wealth both in Indonesia and in other countries. The second of these ideologies, even for Hizbut Tahrir simply handle the sheer worldly affairs, whereas Islam as an ideology not only talks about worldly affairs but also in the afterlife.

Second is an external factor, namely Indonesia political system that uses a liberal democracy. Reform with the spirit of the liberalization which everyone is given freedom to state the opinion, Assembly and association protected by the Constitution. This kind of liberal democracy is a great momentum for the HTI for doing the movement openly. Then be not surprised if HTI openly hold a Caliphate Conference Islamiyah and encourage Governments to uphold the Islamic jurisprudence. In contrast to the new orde, during the Reformation, HTI fight freely to disseminate the ideas of khilfah and establish to pursues the Islamic jurisprudence. However, during the reign of Jokowi, HTI has disbanded and declared illegal organizations.

\section{Indonesia's Economic Reality: Portraits of Social Inequality}

Post-Reformation with the spirit of the (economic) liberalization and privatization is the departure point of the injustice in the country and social imbalances that occur increase rapidly. Social justice as one of the founding ideals of the Republic was still far from the expectations. Practices of injustice against the citizens still occur, is a phenomenon that is already familiar. This form of injustice against the citizens can appear through the policies issued by the State. Often the policies issued by the Government of independence to citizens in General, but more profitable or sided with a group of people, such as employers. On the other hand, sometimes the policies are contradictory between das sein and das sollen. Means, the policies issued by the Government basically aims to bring about a just social order, but in implementation often does not run in accordance with the existing rules. This is due to still strong tradition of CCN (Corruption Cronyism Nepotism) in Indonesia.

Prior to unravel the practices of injustice in this country first will be quoted from a speech presented by Sukarno on 01 June 1945, which became known as the day of the birth of Pancasila (ecision of the Indonesia President Number 24 years 2016 about the birth of Pancasila). Through the speech, Sukarno has exposed the Five Precepts (Pancasila) as Philosofische or basic Grondslag State. Sukarno has explained about Pancasila if squeezed into three Sila (Tri Sila), namely the socio - nationalism, Socio - democracy and the Godhead (speech of Sukarno on 01 June 1945 before trial BPUPKI). The intent of the socio - nationalism is a nationality not only to understand the ideals of the homeland, not only to embody unity. In addition, nationalism based on the humanity, it means no more oppression of man over man, the State of the country as well as the country's top citizens. Because, the suppression case as foreign Nations do not only do a form of injustice. Nevertheless, oppression can be done by his own nation against nation, for example, government policies that are not pro people. Furthermore, the intention of Socio - Democracy is a democracy in the political field also in the field of economics. The intent of the foregoing that the citizen is not merely given the rights to politics only, e.g. channeling his political aspirations when the election comes, however, should be given a guarantee of economic prosperity. From these two points, we can deduce in Indonesia country there is no more oppression of man over man, as well as realize a fair public order and peace.

Although, there are various forms of Justice, both in the fields of law, education, health, economic and others. However, in this explanation will be focused on economic justice. The center of the economy is the basis for relating to others. Although not a factor, but economic determinants can customize the others case, such as religion, ideology, education, legal, and health. Justice in the economic sphere in our country could not materialize as expected in the 1945 Constitution of Indonesia and the Pancasila. Thus, the saddest problem in economics is namely the problem of poverty and economic inequality. Although the Government of Indonesia is capable of lowering poverty to reach 10.86 percent, but Indonesia's economic gap is still very large. This is confirmed by the statement of Finance Minister, Sri Mulyani Supermentor, in the seminar at the XXI Djakarta 
Theater, Central Jakarta, Monday evening, October 17, 2016, which says, "Poverty is indeed down, but the gap widened. One percent of the population controlled 50 percent of the asset" (Sawitri \& Angelina Anjar, 2016)

Statement of the Finance Minister of Indonesia we can see data on Indonesia's economic growth in the year 2016 are experiencing an increase in quarter I, a number of 5.04 percent, while in quarter II reached 5.18 percent, then in quarter III experience increased to 5.3 percent (Setiawan \& Sakina Rakhma Diah, 2016). On the other hand, the Gini ratio index was at the level of 0.4 percent in the year 2015. Even the Gini Ratio in 2017 did not experience significant changes when compared to the year 2016. It could be said to be stagnated. Referring to these figures, we can conclude that there is disparity of income.

Poverty and Gini Coefficient (Rofiq, 2016)
\begin{tabular}{rrr} 
Year & Poverty & Gini Coefficient \\
\hline 2010 & 13,3 & 0,38 \\
\hline 2011 & 12,5 & 0,41 \\
\hline 2012 & 11,7 & 0,41 \\
\hline 2013 & 11,5 & 0,41 \\
\hline 2014 & 11 & 0,41 \\
\hline 2015 & 13,31 & 0,40 \\
\hline 2016 & 10,70 & 0,397 \\
\hline 2017 & 10,64 & 0,394
\end{tabular}

Number in Percent (\%)

The existence of a concentration of wealth is caused by the practices of the oligarchs in Indonesia, coupled with the rise of the tradition of the CCN (Corruption Cronyism Nepotism). It is similar with Jeffrey a. Winters (2011) of the oligarchy is "the power minorities against the majority." Strength of material resources as the basis for strengthening the wealth at the same time is to maintain their wealth. This minority can access the resources of wealth; the goal is to secure his personal wealth at once to enlarge his wealth. So the rich are getting richer, while the poor increasingly suffer. Yet if we look at the policy practices often take over the means of production belong to small people. While on the other hand, small people estranged with the means of production that have been previously owned. As a result, they were thrown into a labor mercenaries or factory workers to the minimum wage.

\section{Caliphate Islamiyah as Solutions to the Social Gap}

Critique of social reality that occurred in Indonesia in "Political Manifesto HTI" is controversial enough (Manifesto Hizbut Tahrir, 2017). The source of the abundant natural resources in the country, it is not proportional with the welfare of the people of Indonesia. Criticism poured in the manifesto set out from two major ideologies ever developed in the world, i.e. socialism-communism and liberalism-capitalism. Both the ideology in practice had failed to realize social justice. Even in Indonesia today under the handling of global capitalism system, social injustice is becoming a common sight. On the other hand, the social inequality becomes wider. Even the two ideologies are simply talking about worldly affairs, would fail in realizing social justice. For the HTI in manifestonya, because "in the absence of the sovereignty of Asy-Syari'. In other words, it is not applied the Islamic system in the middle of the community".

Even Indonesia's political system deemed contrary to the Islamic faith. Departing from the social reality, HTI holds if the Khilafah Islamiyah reestablish, social justice will be created. It also departs from a conviction over the success of Even Khilfah ever run upfront. "Justice and goodness have looked everywhere like in the time of Caliph two Umar (Umar Ibn Khattab and Ibn ' Umar)” (hizbut-tahrir.or.id, 2007). However, HTI himself has agreed a lot of the Caliph as a King, but in the running wheel of governance based on the Islamic system of Government.

Although there is a Caliph who succeeded in realizing justice and welfare for the people, on the other hand there is the Caliph and using his power for personal gain. This can we see at the time of the Caliph Uthman (656 - 661). At the time of Uthman, foedalisme practices and oligarchic nor the collusion has grown. Usman handed the governorship and almost all of the positions submitted to the relative proximity of the Quraish tribe. Even Usman also gave a lot of money to her relatives who had been taken from the Baitul Mal (State Treasury), it is in a modern context is not much different with corrupt practices (Enginer, 1999).

In addition, Usman has issued a policy of liberalization and privatization. Any person permitted to transact buy and sell land freely without any restrictions. At this point, many rich merchants liked the style of leadership of Usman, differ on others Caliph before, because they were able to buy land as you wish. The freedom to purchase land that has an impact on the concentration of wealth (land ownership) on a handful of people, while many people are increasingly impoverished, because it has no ground. The absence of means of production (land) resulted in them (the people) became a slave (labor) for landowners. The presence of such concentrations of wealth leads to social inequality and injustice for small people. In addition, an internal conflict in his own 
Islamic body about leadership succession is also common. Even post, the Islamic prophet Muhammad died; the seeds of conflict have emerged but not hardened. "Before the Prophet was buried, some people have the ambition to succeed Muhammad as leader of the Muslims and the State."

\section{Conclusions and Suggestions}

From the brief overview above, we can conclude under the Caliphate is not always good. A conflict over leadership succession is part of the historical development of Islam itself. Even the caliphate system forever will embody social justice, since in reality it is not least the indisputable. Therefore, if Khilfah Islamiyah reestablish in Indonesia on a later day is very possible usurpation practices through bloodshed. Even as in the time of Uthman himself, social imbalances caused by concentrations of wealth, for the future will be very possible even reestablish Caliphate Islamiyah. However, we should also be critical of the social reality that occurs on this day. The reason is very possible, the rise to reestablishment Islamic jurisprudence in kaphah, it is possible the movements will appear in other forms in response to the realities.

For that the Government needs to be responsive to the reality of the conditions above occurs. Social inequality becomes severe enough homework for the Government of Indonesia. Through his power, Governments need to do a distribution of wealth evenly, with no concentrate on a group of people. It is in accordance with the mandate of the Foundation of the Republic for the creation of a fair public order and peace, in the absence of oppression man over man. If the social gap was still sharp and simultaneous policy practices that are not pro is very possible people will appear other sseparate movements. The separatist movement will of course threatened disintegration of the nation and can trigger the movement of treason. Because those who are not a part in the policy issued by the Government, it is possible will do the rebels.

\section{Reference:}

Ali, A. S. (2017). Mengenal hizbut tahrir yang bertujuan mendirikan khilafah Islamiyah di indonesia”. In: https://www.arrahmah.co.id/2017/04/hizbut-tahrir-dirikan-khilafah-islamiyah-indonesia.html.

Amal, et al (2004). Politik syariat Islam dari Indonesia hingga Nigeria. Jakarta: Pustaka Alvabet,

Anonim. A. (2007). Koferensi khilafah. http://hizbut-tahrir.or.id/2007/08/16/konferensi-khilafah/.

BPH UMY (2012). Gerakan politik hizbut tahrir dalam Sistem politik indonesia. http://www.umy.ac.id/gerakanpolitik-hizbutthahrir-dalam-sistem-politik-indonesia.html.

Chusna, A. (2014). Konsep jihad hizbut tahrir di Indonesia (HTI) dan majelis mujahidin Indonesia (Studi Perbandingan). Islamic State University of Sunan Kalijaga.

Bohm, D. (1984). Causality and chance modern physics. London

Editorial. (2017). Sejarah hizbut tahrir di Indonesia. https://kumparan.com/salmah-muslimah/sejarah-hizbuttahrir-di-indonesia.

Enginer, A. A. (1999). Asal usul dan perkembangan Islam: analisis pertumbuhan sosio-ekonomi. Yogyakarta: Pustaka Pelajar

Erdianto, K. (2017). Pemerintah bubarkan hizbut tahrir Indonesia. http://nasional.kompas.com/read/2017/05/08/14070141/pemerintah.bubarkan.hizbut.tahrir.indonesia.

Hindarto, S. Y. (2017). Hizbut tahrir dan kebangkitan khilafah yang terlarang. http://www.cnnindonesia.com/nasional/20170508152919-20-213180/hizbut-tahrir-dan-kebangkitankhilafah-yang-terlarang.

Indonesia President Nomor 24 Tahun 2016 tentang Hari Lahir Pancasila.

Manifesto Hizbut Tahrir untuk Indonesia: Indonesia Khilafah dan Penyatuan Kembali Dunia Islam. http://hizbuttahrir.or.id/wp-content/uploads/2009/07/manifesto-ht-untuk-indonesia.pdf

Novel. A (2007). $80 \mathrm{ribu}$ umat Islam hadiri konferensi khilafah internasional. http://hizbuttahrir.or.id/2007/08/08/80-ribu-umat-islam-hadiri-konferensi-khilafah-internasional-2/.

Rofiq, A. (2016). Kualitas pertumbuhan dan ketimpangan ekonomi. http://koran-sindo.com/page/news/2016-03$02 / 1 / 1$.

Samarah, I. (1991). "Mafhum al adalah al ijtima'iyah fi al fikri al islami al mu'ashir. http://hizbuttahrir.or.id/2007/05/20/syaikh-taqiyyuddin-an-nabhani-pendiri-hizbut-tahrir/

Sawitri, A. A. (2016). 1 persen penduduk ini menguasai 50 persen aset. https://m.tempo.co/read/news/2016/10/18/087813000/1-persen-penduduk-ini-menguasai-50-persen-aset.

Setiawan, (2016). BI : kuartal III 2016, pertumbuhan ekonomi indonesia belum kuat. http://bisniskeuangan.kompas.com/read/2016/10/20/171945526/bi.kuartal.iii.2016.pertumbuhan.ekonomi.in donesia.belum.kuat.

Shodiq, R. (2016). Sejarah LDK, KAMMI, dan HTI chapter kampus. http://wawasansejarah.com/sejarah-ldkkammi-dan-hti-chapter-kampus/.

The decision letter of the Directorate General of the unity of the nation and the politics of Ministry of Home Affairs Number 44/D.III.2/VI/2006 
The decision letter of the Minister of law and human rights Number: AHU-00282.60.10.2014 about the legality of HTI

Victoria, A. (2013). Sejarah awal masuknya hizbut tahrir ke indonesia. http://www.globalmuslim.web.id/2013/11/sejarah-awal-masuknya-hizbut-tahrir-ke.html.

Winters, J. A. (2011). Oligarki. Jakarta. Gramedia Pustaka Utama. 